
of the Ukrainian Engineering Pedagogics Academy

V. V. Ivanenko

Assistant Professor of the Department of Foreign Languages of the Ukrainian Engineering Pedagogics Academy

\title{
CREATIVE POTENTIAL DEVELOPMENT OF THE STUDENT'S PERSONALITY BY TOOLS OF ENGLISH LANGUAGE
}

Based on the analysis of psychological and educational literature, the article attempted to reveal essence of the concept "creative potential" in the context of modern university education, it is emphasized that creative intellect of students makes foreign language acquisition easier, quicker and more successful. Interactive, communication based exercises, functional-situational based methods play a key role in emphasizing functional and situational using of a foreign language and applying such activities as role-play exercises, simulations requiring students in higher education to use fully their imagination and creative thinking. The development of students' creative capacities focuses on analytical (consistency, mobility, selectivity, quick thinking), creative (effective means of solving the problem, originality), emotional (density of images, emotional evaluation of events, facts, phenomena) components of creative thinking.

The author underlines factors in the development of students' creative activity in the process of teaching a foreign language, defines educational principle and operating environment for teachers, that should be taken into account in the creative activity development (concept of consciousness, creative activity, visibility, regularity and consistency, differentiated approach, communicative learning). The author indicates that such forms and methods of strengthening training actions as play-based methodology, discussion methods and drills techniques are especially the case for students' creative activity development during foreign language learning in high school.

It concluded that the special approach to knowledge transfers from the teacher is a key condition for successful development of students' creative activity. A teacher aimed at training highly skilled specialists, has to work in the updated educational situations, when his/her functions included organization of students' research work, required application of innovative, project, communicative kinds of activity. In this context, it is considered necessary for a teacher to follow the working methods of professional roles, which contribute to the formation of students' creative activity, educational process should aim at developing creative abilities of every student, establishing of the most favorable conditions for realization of his or her abilities and interests.

Key words: creative potential, foreign language, higher school, creative thinking, didactic principles, communicative teaching methods.

Formulation of the problem. The shaping international relations cannot be separated from the learning and teaching process of English language, since it is undoubtedly the means of cross-cultural communication. At present day, Ukrainian society urgently needs highly skilled professionals, capable of speaking fluently in English, leading to a major review of the teaching content at higher educational establishments in the country. A success of a person in all activities is defined by capabilities and respective qualities for them. Intelligence and creativity are necessary for every person in all situations, both relate to the pursuit of knowledge and understanding and to human creativity in a constantly changing world. Intelligence as a form of organization of individual mental experience provides an opportunity to deal, understand and interpret what is happening effectively. The development of creativity (creative abilities) supposes an individual's capacity to under- stand the problems and shortcomings and add value to the experience, generate original ideas.

Intellectual activity and creativity are cumulative and concurrent. Creative process in any intellectual environment cannot be implemented without coherent interesting personality. The creation of conditions for intellectual and creative activity is the basis for the realization of the student-centered approach in education.

Analysis of actual researches. Creative process is identifying indicator of personal life and work, that are conditioned by existence, consciousness, thinking, worldview, attitudes and the need to produce "new things". In reviewing the theoretical position regarding the creative process, it must be noted that one common factor is the process of personal development. It is believed that college student age is the most active period of character-building, when the life skills and capacity for free and creative 
thought are developing, creative activity is becoming a real need, so that is seen as the prime factor in stimulating educational support of student's creative activity and his/her personal-professional development [5, p. 34-37].

From an examination of the creative abilities of student's youth, G.A. Ivashenko underline that " $<\ldots>$ the creative abilities made it possible to carry out activities in various fields of intellectual creation, to find innovative solutions, using different variations" [3, p. 14-17]. Accordingly, brought together the different concepts, it can be argued that creative process is part of human well-being, which not only meets its needs, but is a process of self-development, self-improvement, which distinctive characteristics are discovery significant new and innovative things.

Alan Meley believes that creative intellect of a student contributes to a more efficient teaching and learning process of a foreign language, by helping them cope with completely new life experience. Interactive, communication based exercises, functional-situational based methods play a role in highlighting functional and situational using of a foreign language and application of activities such as role plays, interactive simulations, where the students fully utilize their imagination and creative thinking [8].

Naiman (1998) highlights that creativity is considered as a transformation process of imaginative ideas into reality. According to this author, creativity includes two functions: thinking and producing; and believes that innovation is the generation or application of an idea. If a teacher has some ideas, but cannot act on them, they are considered as an imaginative person but not creative one. In accordance with May (1994) creativity is the process of introducing something new to the culture and demands enthusiasm and dedication. This brings to our consciousness what was hidden beforehand and promotes us get new experience and points of view. Burns and Richards (2009) state that the teacher's contribution to educational process is to increase students' knowledge growth enabling environment to make their underlying knowledge to be examined and challenged.

The aim of this article is to reveal the content of the term "creative activity" in the context of modern higher education based on the analysis of the psychological and educational literature, to highlight the features of the students' creative activity in the process of teaching English for Technology to students of technical universities, to determine didactic's principles and conditions for teachers' activity, that should be taken into account in the process of formation of students' creative activity.

Presentation of the main material. The analysis of methodological works confirms that the creative activity is the highest level of the teaching and educational process and it has been deemed to be an indispensable requirement for the comprehensive development of personal identity of students. The development of students' creative abilities is increasingly being oriented towards creative thinking, namely, the following components:

1) analytical component involves logical thinking (mobility, consistency, association rating, intelligence, selectivity, knowing how to differentiate, etc.);

2) emotional component includes representational thought (vividity of images, emotional evaluation of events, facts, phenomena and so on);

3 ) creative component covers visual active thinking (rational way to address common problems; originality as a manifestation of the student's personality, uniqueness, overcoming the stereotypeness), the ability to predict the results, the commitment to summarize relevant knowledge and skills in the course of activities, to find the most convenient solution among various alternatives and justify their action [4, p. 113-121].

M. Constantinides highlight the following characteristics of students' creative activity development in the process of teaching English:

- fluency - students are able to understand the information at the moment of its perception, to generate a lot of ideas quickly;

- flexibility - learning, cognitive flexibility, what it means to generate different ideas and to see things from different points of view);

- elaboration - students are able to design and use of existing knowledge, the further development of them to expand and complete);

- originality - students are able to produce entirely new set of ideas $[7 ; 8]$.

All those functions listed above are applicable to both teachers and students. However, the process of creative potential development of students requires mandatory monitoring of their activity by teachers. The teacher should guide and support students, help to develop their creative abilities at each lesson. Only in the process of hard work and commitment would it be possible to create the certain features and achieve the students' ownership in English class.

The creativity of English language teacher depends on his/her ability to analyze, to evaluate situations and identify new ways to react to them. This depends, in turn, on a number of various skills and levels of critical, creative and analytical thinking. Creative focus for the teacher's activities makes special style of his/her thinking, which is connected first and foremost with the newness and the relevance of the activity provided, by initiating synthesis of the cognitive, emotional, volition sphere of teacher's personality. Well-developed creative activity need, which is expressed in specific skills plays a key role. Advanced intelligence provides an opportunity for teachers to understand not only particular single teaching facts and phenomena, but also pedagogical 
ideas, training and education theories. Reflexiveness, humanism, clear understanding of the tools, required for teachers' professional development and development of the student's personality are the essence of intellectual competences of educators.

Global society and its inherent mobility offer young individuals the possibility for better training in various fields, making a considerable contribution to their overall capacity to adapt to the increasingly complex requirements of today's dynamic global labor market. The demands of modern society on proficiency in a foreign language of future professionals are constantly growing under the influence of markets' globalization, the implementation of new technologies, and changes in the demands made by both society and employers. This raises whether to do this it is necessary to replace the current teaching methods depending on the context of specific training situations, goals and stage of English learning process.

The academic quality and performance of each teaching methods depends primarily on the foreign language educators, their experience and creative abilities. Since it was the teacher provides conditions for the active application of different linguistic clichés, expressions and phrases for everyday use; motivates the students to communicate in English, to make mistakes without fear and to overcome the language barriers effectively. Thus, a personality of the English teacher, his/her high professionalism, positive psychological micro climate at the lessons and their willingness to assist a student are considered as the basic aspect for evaluation of the quality of English teaching. A teacher should have not only artistic and public speaking abilities, but also skills of analysis, synthesis and evaluation; he/she is expected to have basic knowledge of psycho acoustics and linguodidactics. Practical classes which are emotionally charged, well-organized and filled with various linguistic training content will assist in the developing of student's creative potential.

Creativity relies upon the skills to analyze, estimate situations and determine unusual ways of responding to the situations. This in turn relies upon various abilities and levels of thinking. Some aspect of a teacher's skills and awareness, characterizing the qualities of creative teachers are formulated based on the analysis of psychological and pedagogical literature:

- he/she should have a solid knowledge base in a foreign language and a foreign language teaching. $\mathrm{He} /$ she applies thease skills in organizing creative lessons. It is essential to have knowledge base (it means that the teachers have a motivation and they are aimed at the creative activities they use), due to the fact that imagination is not productive without it;

- a teacher should be confident. This quality of character can enable the teacher to be original and creative; it gives them a sense that they have control over their classroom. A teacher can see the results of his/her lesson as being decisive, and so they have a sense of personal responsibility for how well learners study;

- creative teachers want their students to succeed, so they try to learn as much as they can about their students. Also they try to form their learners' self-confidence;

- the creative teachers look for interesting forms of organizing practical lessons, using the textbooks, training materials and seeks to organize classes, reflecting their individual teaching style;

- creative teachers can apply a broad variety of pedagogical strategies and methods;

- the teachers are ready to try out, to break new ground, and to take risks;

- creative teachers try to carry out student-centred lessons.

Based on the analysis of current scientific psychological and pedagogical literature, the following didactic principles may be identified. The principles should be taken into account during students' creative activity development:

1. The coherence of teaching and learning is a principle of consciousness and creative activity. It is necessary to initiate the cognitive activity with a view to the conscious learning. The students' cognitive activity is primarily their conscientious attitude to English learning and appropriate motivation. Hence, it was closely linked both with the complementing training content, and emotional attitude to it; was conditional on the creating the demand in cognitive activity, that reinforce the volition aimed at obtaining of training information, and is expressed as the respective activities in the training process.

2. The informative principle is to develop a clear, vivid concept of subjects and topics to be examined. The use of visual aids simplifies the semantization of training content, enables the successful application of English as a medium of communication. A variety of visibility affect the students' emotional level by intensifying their willing, by mobilizing functional reserves of students, exacerbating their memory. For instance, the using of visual aids in the learning process of grammatical topics (posters, illustrations, and diagrams) promotes the principles of conscience.

3 . The principle of coherence and consistency is to present the training material based on its internal logic, continuity, dialectic interactions between the previous and the following materials, the development of skills and abilities with the specified system.

4. The progressivity principle is meant to create the conditions for sustainable development of basic competencies for all students, to work with groups of students at multiple learning levels, to take into consideration the individual characteristics of students' academic activity, to work in groups with a view to English concepts learning. 
5. The principle of communicative base of learning involves providing the appropriate conditions in English class to meet the students' need for communication and communicative skills development.

It must be noted that all the above-mentioned principles in the practice are carried out in close cooperation, complement and reinforce each other. The effective development of students' creative activity in English classes can be achieved only if the methodological aspects are in place.

Based on mentioned methodological aspects and taking into account the studies with a practical orientation, it can be said that these enhancing forms and methods of learning process are most common in the development process of students' creative activity in English learning process in a high school. Among them are the following:

- gaming technology involves simulation and role-playing. The creative skills become evident through spontaneous and non-typical situations. The role-plays include characteristics, difficulties, key problems and dynamics of future professional careers. The emotional and important fragments of gaming communication, nonstandard solutions, and components of meaningful analysis are able to become the specific signals to memorize and put into practice the foreign language information the students have learned in their further professional activities. It cannot be argued that a perfectly organized and successfully implemented business game is a very effective means of achieving success in the educational activity, given that there is a pattern in professional activity and the students' apprehension of the theoretical input;

- discussion methods not only increase the students' motivation and inclusion in the learning processes, they also intensify their thought process, contribute to the development and formation of skills thinking independently, expressing views, analyzing and as well to other viewpoints on the issue;

- the method of drills is that the learners are trained to apply the foreign language material in practice and through perpetual actions, deepening English knowledge, creating specific skills and abilities and developing their thinking and creativity;

- brainstorming is carried out through the using of benefits of group activity, group thinking, spontaneous making assumptions, that contributes to an increase in the number of generated by the variety of ideas, enables to develop the point of view of other participants, and therefore to develop the students' creative activity. The principles of brainstorming method (proposed by A. Osborn) are: the generation of ideas, resulting in creative problem-solving; the application of effects of group activity, collective thinking, group dynamics, the techniques of association; spontaneous making assumptions; the delayed assessment, that have contributed to increase the number of generated ideas.
An in-depth theoretical analysis of some pedagogical methods shows that the creation of psychological and pedagogical conditions for students to take an active position and "open up" as a subject of the educational activity is the most typical direction for increasing university education's efficiency. Accordingly, it is necessary to highlight that we will follow during the training process of students:

1) the organization of the training, creative and other forms of activities, taking into account their interests and abilities;

2) the gradual increase in complexity, difficulties, problematic objectives and tasks;

3) organizing competitions, contests, exhibitions, Olympiads, the students' creative achievements;

4) the valuation of that form of creative activity, where a student can realize herself/himself as a person;

5) the praise and appreciation of students in case of his/her special creative achievements.

We need to accept that Olympiads and contests in a foreign language play a great role to raise the creative activity of the training process. It is well known that the students are seeking to broaden their minds, the development of skills for individual work take place, participating in these creative competitions.

Conclusions and perspectives of further research. Democratization and humanization of the pedagogical process in a higher educational establishment present new demands for teachers and students' activity. They lie in unleashing the cultural, creative and ethical potential as well as a student and a teacher, in changing their relationships based on cooperative learning with the student's active position. The pedagogical process should aim at developing creative abilities of every student, at creating of maximum favorable conditions for demonstration of their abilities and interests. Therefore, nowadays, we consider the student's creative activity not only as a means of acquisition of knowledge, skills and values but also as the most important source of intellectual and creative development of students.

Study and assimilation of the psychological and pedagogical literature, best pedagogical practices suggest that a process of continuous improvement of the content of education has led to a reduction of the student's passive position and caused the development of their creative abilities, resulting in identification the student's hidden capacities, their skills for solving specific tasks and demonstration of creative approach to their solutions, the student's aspiration to a continuous learning process, a relatively high level of their adaptability and academic mobility, etc. However, in our view, the specific approach to transfer the knowledge with the assistance of the tutor is a key requirement for successful developing of the students' creative activity. A teacher, aimed at the training of successful specialists, should 
work in renewed pedagogical situations, when his/ her functions include carrying out research work together with students, demands to apply innovative, and projective, communicative kinds of activity.

\section{References:}

1. Астахова В.И. Студент XXI века: его сущностные черты и характерные особенности. Alma mater. Вестник высшей школы. 2010. № 8. C. 60-63.

2. Кудрявцев В.Т. Творческая природа психики человека. Вопросы психологии. 1990. № 3. C. 113-121.

3. Мелхорн Г., Мелхорн К.Г. Творческое мышление и творческая деятельность студента. Современная высшая школа. 1982. № 3. C. 34-37.
4. Національна доктрина розвитку освіти України у XXI столітті. Вища освіта в Україні: нормативно-правове регулювання / за заг. ред. А.П. Зайця, В.С. Журавського. Київ : Форум, 2003. C. 113-121.

5. Тлегенова Т.Е. Студент как субъект формирования опыта творческой деятельности. Молодой ученый. 2011. № 8. Т. 2. С. 138-140.

6. Maley A. Creativity with a small "c". The Journal of the Imagination in Language Learning and Teaching / ed. by C. Coreil. 1997. Vol. 4. URL: http://www.njcu.edu/cill/journal-index.html.

7. Creativity in ELT. URL: http://worldteacher-andrea. blogspot.com/2012/07/creativity-in-elt.html.

8. ConstantinidesM.TheArtofBeingCreative.URL:http:// marisacinstantantinides.edublog.org/2010/04/13/ the-art-of-being-creative/\#.VqMzeBpunIU.

\section{Подорожна А. О., Іваненко В. В. Розвиток творчого потенціалу особистості студента засобами англійської мови \\ На основі аналізу психолого-педагогічної літератури у статті розкривається суть поняття} «творчий потенціал» у контексті сучасної вищої освіти. Автори визначають, що творчий інтелект студента допомагає організувати процес засвоєння іноземної мови на більи продуктивному рівні. Комунікативні методи навчання відіграють ключову роль, оскільки вони підкреслюють функціональне й ситуаційне використання іноземної мови та використання таких видів діяльності, як рольові ігри, моделювання ситуацій, що потребують від студентів застосування в повному обсязі своєї уяви й креативного мислення. Формування креативних здібностей у студентів орієнтується на розвиток аналітичних (послідовність, мобільність, селективність, асоціативність, кмітливість), креативних (пошук раціональних засобів розв'язання проблеми, оригінальність), емоційних (насиченість образів, емоційне оцінювання подій, фрактів) компонентів креативного мислення.

Автори окреслюють особливості розвитку креативної активності студентів у процесі викладання іноземної мови, визначають дидактичні принципи й умови діяльності педагога, які варто брати до уваги у процесі формування креативної активності студентів (принцип свідомості та творчої активності, наочності, систематичності й послідовності, дифреренційованого підходу, комунікативної основи навчання). Автори наголошують на тому, що ігрові, дискусійні методи та методи вправ - це найбільш характерні форми й методи активізації навчального процесу для формування креативної активності студентів у процесі опанування іноземної мови у вищому навчальному закладі.

Зроблено висновок, що однією з головних умов для результативного фрормування креативної активності студентів є особливий підхід до передачі знань із боку викладача. Викладач, який орієнтується на підготовку успішних фрахівців, зобов'язаний працювати в оновлених педагогічних ситуаціях, коли його фрункції передбачають здійснення науково-дослідної роботи зі студентами, вимагають засвоєння інноваційних, проектувальних, комунікаційних видів діяльності. Із цією метою викладачеві варто використовувати методи роботи у профессійних ролях, які сприяють розвитку креативної активності у процесі фрахової підготовки майбутніх висококваліфрікованих спеціалістів. Процес викладання іноземної мови у вищій школі має бути орієнтований на фрормування творчих якостей особистості кожного студента, організацію сприятливих умов для прояву його здібностей та інтересів.

Ключові слова: креативна активність, іноземна мова, вищий навчальний заклад, креативне мислення, дидактичні принципи, комунікативні методи навчання. 